Palczewicz H. T., Kandydat n. Ekon., Profesor Centralnoukraiński Narodowy Uniwersytet Techniczny m. Kropywnycki, Ukraina

DOI: https://doi.org/10.30525/978-9934-26-028-5-52

\title{
MODERNIZACJA MECHANIZMÓW FINANSOWANIA W GOSPODARCE CYFROWEJ
}

Wdrażanie technologii cyfrowych w procesie rozwoju gospodarki innowacyjnej jest aspektem priorytetowym. Na skutek czego, oprócz bezpośredniego wzrostu produktywności, również powstaje szereg pośrednich korzyści wynikających $\mathrm{z}$ cyfryzacji. Generalnie to oszczędność czasu, tworzenie zapotrzebowania na nowe produkty i świadczenia usług, aktualizacja pod względem podejścia do ich jakości oraz wartości, etc. [1]. 
Znaczące przyspieszenie rozwoju procesów cyfryzacji zostało spowodowane przez pandemię. Zaistniała sytuacja odźwierciedliła silną potrzebę dokonywania operacji finansowych w trybie on-line. Co znacznie zwiększyło korzystanie $\mathrm{z}$ usług pośrednictwa finansowego oraz czynności bankowych przez Internet. Podobne podejście jest korzystne w sytuacji, gdy jeden lub wielu uczestników stosunków finansowych potrzebują wykonać operację finansową na odległość. Ponadto jako istotna zaleta korzystania $\mathrm{z}$ technologii cyfrowych w sektorze finansowym jest znacząca oszczędność czasu dzięki brakowi potrzeby przybycia do oddziału bankowego oraz ominięcie kolejek.

Ogromnym przełomem w tym obszarze jest technologia rozproszonych rejestrów (ang. Distributed Ledger Technology, $D L T)$, w tym technologia Blockchain. Brak centrum sterowania jest jedną z najbardziej charakterystycznych cech danej technologii. Blockchain funkcjonuje bez pośredników, regulatorów oraz instytucji kontrolnych. Ważność wszystkich zawartych umów jest potwierdzana przez sieć i jej uczestników. Światowe banki, takie jak Goldman Sachs, JP Morgan, Credit Suisse i Barclays, wspólnie pracują nad rozwojem danej technologii. Blockchain wzbudza zainteresowanie wśród instytucji finansowych tym, iż ma szereg niezaprzeczalnych korzyści, takich jak: obniżenie kosztów obsługi, zwiększenie szybkości transakcji oraz przejrzystości w wyniku zmniejszenia roli czynnika ludzkiego. Przy czym również ma miejsce wysoki poziom ochrony i bezpieczeństwa wykonywanych operacji.

Oprócz tego do głównych współczesnych trendów cyfrowych zaliczamy: rozwój Internetu Rzeczy (ang. Internet of things, IoT); transformacje cyfrowe zarówno pojedynczych przedsiębiorstw, jak i całych sektorów gospodarki; ekonomia współdzielenia (ang. sharing economy); wirtualizacja infrastruktury fizycznej systemów informatycznych; inteligencja sztuczna (ang. Artificial intelligence, AI); platformy cyfrowe.

Projekt „Strategia Produktywności 2030” przedstawiony przez Ministerstwo Rozwoju zawiera następującą treść: «Transformacja cyfrowa jako środek do podnoszenia konkurencyjności i inno- 
wacyjności przedsiębiorstw wymaga nowego systemu wsparcia niwelującego ryzyko związane ze zmianą modelu biznesowego. Mechanizmy powinny zostać dostosowane do specyfiki procesu cyfryzacji, wspierając inwestycje w takie elementy jak: infrastruktura, kompetencje czy doradztwo technologiczne i biznesowe» [2].

Najbardziej znaczące zmiany z technologicznego punktu widzenia zachodzą $w$ takich sektorach działalności finansowej jak: system płatności i rozliczeń (payments), depozyty i pożyczki (deposit and lending), ubezpieczenia (insurance), zarządzanie inwestycjami (investment management), pozyskiwanie kapitału (capital rising), zaopatrzenie rynku (market provisioning) [3].

Do ,ekosystemu” technologii finansowych (FinTech) zaliczamy:

- duże firmy technologiczne, działalność których obejmuje więcej niż tylko świadczenie usług finansowych;

- firmy, działalność których jest ukierunkowana na ułatwienie transakcji finansowych (MasterCard, Fiserv, First Data);

- duże, dobrze zorganizowane instytucje finansowe, w szczególności Bank of America, Chase, Wells Fargo, Allstate;

- szybko rozwijające się firmy, przeważnie start-upy nastawione na konkretną innowacyjną technologię lub proces. Do najbardziej sukcesywnych należą: Stripe (płatności mobilne), Betterment (inwestowanie zautomatyzowane), Prosper (pożyczki peer-to-peer), Moven (bankowość detaliczna) oraz Lemonade (ubezpieczenia) [4].

Możliwości, którymi dysponujemy w dniu dzisiejszym sprzyjają rozwoju handlu elektronicznego. Są one związane przede wszystkim z wykorzystaniem technologii cyfrowych a mianowicie z rozszerzeniem metod płatności, wykorzystaniem pieniądza elektronicznego, pożyczek internetowych, inteligentnej logistyki oraz usług powiązanych. Ważnym aspektem jest udoskonalenie umiejętności cyfrowych obywateli i rozwój transgranicznego handlu elektronicznego.

Rozwojowi branży bankowej w obliczu cyfryzacji gospodarki towarzyszy wdrażanie innowacyjnych produktów i technologii bankowych. Trwa proces emisji kart płatniczych z możliwością dokonywania transakcji zbliżeniowych. Unowocześniane są aplikacje 
mobilne, które umożliwiają klientom szybkie i wygodne korzystanie z usług bankowych. Modele biznesowe relacji między bankami a klientami ulegają istotnym zmianom w kierunku zdalnego świadczenia usług bankowych.

Zjawiskiem w innowacyjnym rozwoju instytucji bankowych jest powstawanie banków wirtualnych, które świadczą usługi bankowe i płatnicze bez tradycyjnej infrastruktury oddziałów bankowych. Usługi finansowe świadczone przez bank wirtualny obejmują możliwość korzystania z klasycznych lub wirtualnych kart płatniczych, depozytów mobilnych czy mobilnych narzędzi do budżetowania oraz cyfrowych rachunków w czasie rzeczywistym. Również jest możliwość dokonywania transakcji powiązanych $\mathrm{z}$ płatnościami spersonalizowanymi z wykorzystaniem numerów telefonów, poczty elektronicznej bądź identyfikatorów w mediach społecznościowych.

Jednym $\mathrm{z}$ priorytetowych zadań banku centralnego ma być wszechstronne wspieranie rozwoju technologii finansowych a także współpracy między bankami a przedsiębiorstwami fintechowymi. Szczególną uwagę należy zwrócić na aktywny rozwój takich obszarów jak bankowość cyfrowa, płatności elektroniczne, ubezpieczenia (ubezpieczenia samochodowe, ubezpieczenia podróżne) oraz pożyczki cyfrowe. W związku z czym priorytetowe działania banku centralnego powinny być ukierunkowane na opracowanie krajowej strategii integracji finansowej, stworzenie fintechowej platformy komunikacyjnej, wdrożenie europejskiej dyrektywy płatniczej PSD2 oraz utworzenie Centrum Ochrony Cyberprzestrzeni dla systemu bankowego.

FinTech sprawdzają się w branży ubiezpiczeniowej, gdy niezbędne jest opracowywanie i gromadzenie dużej ilości danych.

Potwierdzeniem temu jest sukcesywny rozwój firmy ubezpieczeniowej „Limonade”. Firma ta prowadzi swoją działalność w oparciu o sztuczną inteligencję oraz ekonomię behawioralną. Lemonade zastępuje tradycyjny model ubezpieczeniowy na model, w którym płatności dokonywane są niemal natychmiastowo $\mathrm{z}$ uwzględnieniem wygodnych dla klienta warunków współpracy. Kluczową kwestią jest to, że firma ubezpieczeniowa „Lemonade” nie 
otrzymuje żadnych korzyści, jeśli opóźnienie wypłaty świadczeń wynika z jej winy, jak to może się wydarzyć podczas współpracy z tradycyjnymi ubiezpieczycielami. Firma ta uzyskuje dochód ze stałej kwoty, zapłaconej za świadczone przez nią usługi.

Również należy brać pod uwagę to, iż cyfryzacja coraz większej iłości dziedzin życia będzie prowadzić do wzrostu cyberprzestępczości. Dlatego państwo musi dołożyć wszelkich starań w zakresie wdrażania i wykorzystywania bezpiecznych pod względem informacyjno-komunikacyjnym systemów, platform oraz infrastruktur. Bezpieczeństwo informacyjne, cyberbezpieczeństwo, ochrona danych osobowych, ochrona prywatności i praw użytkowników technologii cyfrowych, wzmocnienie i ochrona zaufania w cyberprzestrzeni jest w szczególności warunkiem jednoczesnego rozwoju cyfrowego oraz odpowiedniego zapobiegania i łagodzenia związanych z nim zagrożeń.

Państwo musi promować produktywną współpracę między podmiotami gospodarki cyfrowej, zwłaszcza na poziomie międzynarodowym, w celu zapewnienia narodowego bezpieczeństwa cybernetycznego. Skuteczne wdrożenie FinTech wiąże się ze zwiększeniem bezpieczeństwa dla każdego użytkownika cyfrowych usług finansowych.

\section{Piśmiennictwo:}

1. Ekonomichna stratehiia Ukrainy 2030.Ukrainskyi instytut maibutnoho. URL: https://strategy.uifuture.org/index.html.

2. Strategia Produktywności 2030 projekt. Ministerstwo Rozwoju wer. 29.09.2020. URL: https://www.google.com/search?q=Cyfryzacja+gospodarki+w+ warunkach+pandemie $\% 3 \mathrm{~A}+$ procesy $\% 2 \mathrm{C}+$ strategie $\% 2 \mathrm{C}+$ technologie $\& \mathrm{rlz}=1 \mathrm{C} 1 \mathrm{OKW}$ M_ruUA907UA907\&oq=Cyfryzacja+gospodarki+w+warunkach+pandemie $\% 3 \mathrm{~A}+$ pro cesy $\% 2 \mathrm{C}+$ strategie $\% 2 \mathrm{C}+$ technologie $\&$ aqs $=$ chrome..69i57.1438j0j7\&sourceid=chrom e\&ie=UTF-8.

3. Mazaraki A., Volosovych S. Fintech u systemi suspilnykh transformatsii. Visnyk KNTEU. 2018. № 2. S. 5-16.

4. What is FinTech? URL: https://www.pwc.com/us/en/financial-services/ publications/viewpoints/assets/pwc-fsi-what-isfintech.pdf. 